\title{
Faktor-faktor yang mempengaruhi ibu dalam memberikan imunisasi rutin lengkap di wilayah kerja Puskesmas Inuman
}

\author{
Rendi Randika ${ }^{1}$, Suci Amin ${ }^{2}$, Optimis Sriwati ${ }^{3}$ \\ ${ }^{1,2,3}$ Sekolah Tinggi Ilmu Kesehatan (STIKes) Al Insyirah Pekanbaru \\ *Correspondent Email : 08rendi@gmail.com
}

\begin{abstract}
Diterima: 13 Agustus 2021 | Disetujui: 30 Agustus 2021 | Diterbitkan: 31 Agustus 2021
Abstract. Infant and toddler mortality rates due to diseases that can be prevented by immunization still show quite high rates. Basic immunization serves to protect and reduce the risk of morbidity and mortality from diseases that can be prevented by immunization. The purpose of this study was to determine the factors that influence mothers in providing routine routine immunizations in the work area of Inuman Health Center. This type of research is observational analytic with the "cross sectional" approach. The population in this study is mothers who have under two years (under two years) with a sample of 176 people with a sampling technique is purposive sampling. Data were analyzed by Univariate and Bivariate with Chi Square Test. Statistical test results found that there is a significant relationship between knowledge factors ( $p$ value: $0,000<\alpha$ 0.05), education ( $p$ value: $0.018<\alpha 0.05$ ), employment ( $p$ value: $0,000<\alpha 0.05$ ), attitude ( $p$ value: $0,000<\alpha$ 0.05), income ( $p$ value: $0,000<\alpha$ $0.05)$, family support ( $p$ value: $0,000<\alpha 0.05$ ) and affordability to the posyandu service center ( $p$ value: $0,000<\alpha 0.05)$ towards the provision of complete routine immunizations in the Inuman Community Health Center Work Area. It is recommended that the results of this study be considered by Inuman Health Center to conduct health promotion in the form of education about the importance of immunization for mothers who have babies and their families.
\end{abstract}

Keywords: Immunization, Knowledge, Attitude

Angka kematian bayi dan balita akibat penyakit yang dapat dicegah dengan imunisasi masih menunjukkan angka yang cukup tinggi. Menurut data dari UNICEF (United Nations Children's Fund) tahun 2010, 1,4 juta balita seluruh dunia meninggal karena penyakit yang dapat dicegah dengan imunisasi.Kasus PD3I di Indonesia pada tahun 2014 menurut data dari Kemenkes RI tentang Profil Kesehatan Indonesia Tahun 2014 menunjukkan jumlah penyakit tetanus neonatorum sebesar $64,3 \%$ meningkat dari tahun sebelumnya yang sebesar 53,8\% dengan jumlah meninggal 54 kasus. Penyakit campak terdapat pada 12.943 kasus meningkat dari tahun 2013 sebesar 11.521 kasus dan difteri sebanyak 396 kasus dengan jumlah kasus meninggal sebanyak 16 kasus (Kemenkes RI, 2014).

Komitmen internasional untuk meningkatkan derajat kesehatan anak salah satunya dengan program UCI (Universal Child Immunization), yaitu suatu keadaan tercapainya secara lengkap imunisasi dasar pada bayi (anak usia kurang dari satu tahun). Sejak tahun 2014 target UCI di Indonesia sebesar $100 \%$ setiap desa/kelurahan, angka ini dimaksudkan untuk mengurangi kejadian PD3I di Indonesia (Depkes RI, 2009).

Berdasarkan data cakupan imunisasi di Puskesmas Inuman bulan Desember tahun 2018 didapatkan bahwa dari 14 desa yang berada di Wilayah kerja Puskesmas Inuman yaitu desa Bedeng Sikuran, Desa Banjar Nan Tigo, Desa Pulau Panjang Hilir, Pulau Panjang Hulu, Pasar Inuman, Pulau Sipan, Koto Inuman, Sigaruntuang, Pulau Busuk, Pulau Busuk Jaya, Seberang Pulau Busuk, Labuh Lurus, Kampong Baru Koto dan Desa Ketapang Jaya belum ada yang berhasil mencapai standart UCI (Universal Child Immunization). Dari jumlah sasaran 177 bayi dengan persentase pencapaian IDL sebanyak 37,2\%. Angka cakupan imunisasi yang masih rendah tersebut tidak terlepas dari perilaku kesehatan khususnya orang tua anak terhadap imunisasi.

Faktor-faktor pada ibu seperti pengetahuan, pendidikan, pekerjaan, sikap, dan sebagainya akan sangat mempengaruhi pemberian imunisasi dasar anak. Pengetahuan ibu tentang pentingnya imunisasi akan menjadi motivasi ibu membawa anaknya untuk di imunisasi. Beberapa masalah terkait pengetahuan ibu seperti ketidaktahuan ibu akan pentingnya imunisasi, ketidaktahuan waktu yang tepat untuk mendapatkan imunisasi dan ketakutan akan efek samping yang ditimbulkan imunisasi menjadi penyebab anak terkena PD3I. Sikap ibu yang positif terhadap imunisasi akan menjadi dasar tindakan ibu membawa anak ke pelayanan imunisasi. Faktor lain seperti dukungan keluarga, pekerjaan, pendapatan keluarga, dan terjangkaunya tempat pelayanan juga perlu menjadi bahan evaluasi (Pratiwi, 2012). Dari uraian tersebut 
menunjukkan bahwa faktor dari ibu sangat berperan penting terhadap kelengkapan imunisasi dasar pada bayi.

Beberapa penelitian yang telah dilakukan menunjukkan hubungan yang bermakna antara faktor internal ibu dengan pemberian imunisasi dasar anak. Penelitian yang dilakukan oleh Pratiwi tahun 2012 menunjukkan hubungan yang bermakna antara pendidikan ibu dengan pemberian kelengkapan imunisasi balita. Ibu yang tidak bersekolah memiliki resiko 3,814 kali untuk pemberian imunisasi tidak lengkap dibanding ibu yang tamat perguruan tinggi (Pratiwi, 2012), sementara penelitian yang dilakukan oleh Istriyati di Desa Kumpulrejo kota Salatiga tahun 2011 menunjukkan ibu yang berpendidikan dasar memiliki resiko 4,297 kali tidak memberikan imunisasi dasar lengkap kepada anaknya dibanding ibu yang berpendidikan lanjut. Pemberian pekerjaan ibu berhubungan cukup besar yakni 7,667 kali dibanding ibu yang tidak bekerja. Faktor lain seperti sikap ibu terhadap imunisasi, pekerjaan ibu, dukungan keluarga, jumlah pendapatan, dan jarak tempat pelayanan imunisasi menunjukkan hubungan yang variatif. Data tersebut menjukkan faktor-faktor dari ibu terkait imunisasi akan sangat menentukan pemberian kelengkapan imunisasi anak (Istriyati, 2011).

Peran seorang ibu dalam program imunisasi sangat penting, sehingga pemahaman tentang imunisasi sangat diperlukan. Hal ini terkait beberapa hal yang mendasari masih rendahnya angka kunjungan ibu ke pelayanan kesehatan untuk mendapatkan imunisasi sehingga perlu dicari penyebabnya untuk dijadikan bahan evaluasi. Berdasarkan masalah tersebut diatas maka peneliti ingin mengetahui lebih dalam lagi tentang "Faktor-Faktor Yang Mempengaruhi Ibu Dalam Memberikan Imunisasi Rutin Lengkap Di Wilayah Kerja Puskesmas Inuman”.

\section{METODE PENELITIAN}

Jenis penelitian ini adalah analitik observasional dengan pendekatan cross sectional. Penelitian ini telah dilaksanakan pada bulan September 2019 sampai bulan Oktober 2019 di Wilayah Kerja Puskesmas Inuman. Populasi dalam penelitian ini adalah ibu yang memiliki baduta (Bawah Dua Tahun) yaitu sebanyak 314 orang yang berada di wilayah Kerja Puskesmas Inuman. Teknik pengambilan sampel dalam penelitian ini adalah purposive sampling, dengan jumlah sampel 176 orang. Analisis data penelitian yang digunakan adalah analisis data univariate dan bivariate. Data disajikan dalam bentuk crosstab. Analisis data dilakukan untuk menguji hubungan tiap variabel yang selanjutnya dianalisis secara statistik dengan menggunakan uji Chi-Square $\left(X^{2}\right)$ dengan tingkat kepercayaan 95\% $(\alpha=0,05)$.

\section{HASIL}

Berdasarkan hasil penelitian maka peneliti dapat menjabarkan data hasil penelitian berdasarkan analisis univariate dan bivariate sebagai berikut :

Tabel 1. Hubungan Tingkat Pengetahuan Ibu Terhadap Imunisasi Dengan Pemberian Imunisasi Rutin Lengkap Di Wilayah Kerja Puskesmas Inuman

\begin{tabular}{|c|c|c|c|c|c|c|c|}
\hline \multirow[t]{3}{*}{ Pengetahuan } & \multicolumn{4}{|c|}{$\begin{array}{l}\text { Pemberian Imunisasi Rutin } \\
\text { Lengkap }\end{array}$} & \multirow{2}{*}{\multicolumn{2}{|c|}{ Jumlah }} & \multirow[t]{2}{*}{$\mathrm{P}_{\text {Value }}$} \\
\hline & \multicolumn{2}{|c|}{ Diberikan } & \multicolumn{2}{|c|}{$\begin{array}{c}\text { Tidak } \\
\text { Diberikan }\end{array}$} & & & \\
\hline & $\mathrm{f}$ & $\%$ & $\mathrm{~F}$ & $\%$ & $\mathrm{~F}$ & $\%$ & 0,000 \\
\hline Baik & 62 & 35,2 & 19 & 10,8 & 81 & 46,0 & \\
\hline Cukup & 33 & 18,8 & 6 & 3,4 & 39 & 22,2 & \\
\hline Kurang & 4 & 2,3 & 52 & 29,5 & 56 & 31,8 & \\
\hline Total & 99 & 56,2 & 77 & 43,8 & 176 & 100 & \\
\hline
\end{tabular}

Sumber: Data Peneliti (2020)

Berdasarkan tabel 1 diketahui bahwa dari 56 responden dengan kategori pengetahuan kurang hanya $2,3 \%$ yang memberikan imunisasi rutin lengkap sedangkan 29,5\% responden tidak memberikan imunisasi rutin lengkap pada anaknya. Hasil uji statistik dengan menggunakan uji Pearson Chi-square diperoleh nilai $\mathrm{p}$ value $=0,000 \mathrm{p}<\alpha(0,05)$ artinya ada hubungan yang signifikan antara pengetahuan terhadap imunisasi dengan pemberian imunisasi rutin lengkap di Wilayah Kerja Puskesmas Inuman. 
Tabel 2. Hubungan Pendidikan Terhadap Pemberian Imunisasi Rutin Lengkap Di Wilayah Kerja Puskesmas Inuman

\begin{tabular}{|c|c|c|c|c|c|c|c|}
\hline \multirow[t]{3}{*}{ Pendidikan } & \multicolumn{4}{|c|}{$\begin{array}{l}\text { Pemberian Imunisasi Rutin } \\
\text { Lengkap }\end{array}$} & \multirow{2}{*}{\multicolumn{2}{|c|}{ Jumlah }} & \multirow[t]{2}{*}{$\mathrm{P}_{\text {Value }}$} \\
\hline & \multicolumn{2}{|c|}{ Diberikan } & \multicolumn{2}{|c|}{$\begin{array}{c}\text { Tidak } \\
\text { Diberikan }\end{array}$} & & & \\
\hline & $\mathrm{f}$ & $\%$ & $\mathrm{~F}$ & $\%$ & $\mathrm{~F}$ & $\%$ & 0,018 \\
\hline Rendah & 53 & 30,1 & 56 & 31,8 & 109 & 61,9 & \\
\hline Menengah & 31 & 17,6 & 11 & 6,2 & 42 & 23,9 & \\
\hline Tinggi & 15 & 8,5 & 10 & 5,7 & 25 & 14,2 & \\
\hline Total & 99 & 56,2 & 77 & 43,8 & 176 & 100 & \\
\hline
\end{tabular}

Berdasarkan tabel 2 diketahui bahwa dari 109 responden yang memiliki pendidikan rendah hanya $30,1 \%$ responden yang memberikan imunisasi rutin lengkap pada bayinya sementara $31,8 \%$ responden lainnya tidak memberikan imunisasi rutin lengkap pada bayinya. Hasil uji statistik dengan menggunakan uji Pearson Chi-square diperoleh nilai $\mathrm{p}$ value $=0,018 \mathrm{p}<\alpha(0,05)$ artinya ada hubungan yang signifikan antara pendidikan dengan pemberian imunisasi rutin lengkap di Wilayah Kerja Puskesmas Inuman.

Tabel 3. Hubungan Pekerjaan Terhadap Pemberian Imunisasi Rutin Lengkap di Wilayah Kerja Puskesmas Inuman

\begin{tabular}{|c|c|c|c|c|c|c|c|c|}
\hline \multirow[t]{3}{*}{ Pekerjaan } & \multicolumn{4}{|c|}{$\begin{array}{l}\text { Pemberian Imunisasi Rutin } \\
\text { Lengkap }\end{array}$} & \multirow{2}{*}{\multicolumn{2}{|c|}{ Jumlah }} & \multirow[t]{2}{*}{$\mathrm{P}_{\text {Value }}$} & \multirow[t]{2}{*}{$\begin{array}{c}\text { OR } \\
(95 \% \mathrm{CI})\end{array}$} \\
\hline & \multicolumn{2}{|c|}{ Diberikan } & \multicolumn{2}{|c|}{$\begin{array}{l}\text { Tidak } \\
\text { Diberikan }\end{array}$} & & & & \\
\hline & $\mathrm{f}$ & $\%$ & $\mathrm{~F}$ & $\%$ & $\mathrm{f}$ & $\%$ & 0,000 & 0,32 \\
\hline Bekerja & 99 & 56,2 & 47 & 26,7 & 146 & 83,0 & & $(0,254-$ \\
\hline Tidak Bekerja & 0 & 0 & 30 & 17,0 & 30 & 17,0 & & $0,407)$ \\
\hline Total & 99 & 56,2 & 77 & 43,8 & 176 & 100 & & \\
\hline
\end{tabular}

Berdasarkan tabel 3 diketahui bahwa dari 30 responden yang tidak bekerja tidak ada seorang pun yang memberikan imunisasi rutin lengkap pada anaknya yaitu $100 \%$. Hasil uji statistik dengan menggunakan uji Pearson Chi-square diperoleh nilai $\mathrm{p}$ value $=0,000 \mathrm{p}<\alpha(0,05)$ artinya ada hubungan yang signifikan antara pekerjaan dengan pemberian imunisasi rutin lengkap di Wilayah Kerja Puskesmas Inuman. Analisis nilai $\mathrm{OR}=0,32$ artinya responden yang tidak bekerja berpeluang 0,32 kali untuk tidak memberikan imunisasi rutin lengkap.

Tabel 4. Hubungan Sikap Ibu Terhadap Pemberian Imunisasi Rutin Lengkap Di Wilayah Kerja Puskesmas Inuman

\begin{tabular}{|c|c|c|c|c|c|c|c|c|}
\hline \multirow[t]{3}{*}{ Sikap Ibu } & \multicolumn{4}{|c|}{$\begin{array}{l}\text { Pemberian Imunisasi Rutin } \\
\text { Lengkap }\end{array}$} & \multirow{2}{*}{\multicolumn{2}{|c|}{ Jumlah }} & \multirow[t]{2}{*}{$\mathrm{P}_{\text {Value }}$} & \multirow[t]{2}{*}{$\begin{array}{l}\text { OR } \\
(95 \% \mathrm{CI})\end{array}$} \\
\hline & \multicolumn{2}{|c|}{ Diberikan } & \multicolumn{2}{|c|}{$\begin{array}{l}\text { Tidak } \\
\text { Diberikan }\end{array}$} & & & & \\
\hline & $\mathrm{f}$ & $\%$ & $\mathrm{~F}$ & $\%$ & $\mathrm{~F}$ & $\%$ & 0,000 & 0,31 \\
\hline Positif & 99 & 56,2 & 45 & 25,6 & 144 & 81,8 & & $(0,245-$ \\
\hline Negatif & 0 & 0 & 32 & 18,2 & 32 & 18,2 & & $0,398)$ \\
\hline Total & 99 & 56,2 & 77 & 43,8 & 176 & 100 & & \\
\hline
\end{tabular}

Berdasarkan tabel 4 diketahui bahwa dari 32 responden dengan sikap dalam kategori negative semuanya tidak memberikan imunisasi rutin lengkap pada bayinya. Hasil uji statistik dengan menggunakan uji Pearson Chi-square diperoleh nilai $\mathrm{p}$ value $=0,000 \mathrm{p}<\alpha(0,05)$ artinya ada hubungan yang signifikan antara sikap dengan pemberian imunisasi rutin lengkap di Wilayah Kerja Puskesmas Inuman.

Analisis nilai $\mathrm{OR}=0,31$ artinya responden yang memiliki sikap dalam kategori negatif berpeluang 0,31 kali untuk tidak memberikan imunisasi rutin lengkap. 
Tabel 5. Hubungan Pendapatan Terhadap Pemberian Imunisasi Rutin Lengkap Di Wilayah Kerja Puskesmas Inuman

\begin{tabular}{|c|c|c|c|c|c|c|c|c|}
\hline \multirow[t]{3}{*}{ Pendapatan } & \multicolumn{4}{|c|}{$\begin{array}{l}\text { Pemberian Imunisasi Rutin } \\
\text { Lengkap }\end{array}$} & \multirow{2}{*}{\multicolumn{2}{|c|}{ Jumlah }} & \multirow[t]{2}{*}{$\mathrm{P}_{\text {Value }}$} & \multirow{2}{*}{$\begin{array}{l}\text { OR } \\
(95 \% \\
\text { CI) }\end{array}$} \\
\hline & \multicolumn{2}{|c|}{ Diberikan } & \multicolumn{2}{|c|}{$\begin{array}{c}\text { Tidak } \\
\text { Diberikan }\end{array}$} & & & & \\
\hline & $\mathrm{f}$ & $\%$ & $\mathrm{~F}$ & $\%$ & $\mathrm{f}$ & $\%$ & 0,000 & 3,43 \\
\hline Tinggi & 82 & 46,6 & 45 & 25,6 & 127 & 72,2 & & $(1,718-$ \\
\hline Rendah & 17 & 9,7 & 32 & 18,2 & 49 & 27,8 & & $0,849)$ \\
\hline Total & 99 & 56,2 & 77 & 43,8 & 176 & 100 & & \\
\hline
\end{tabular}

Berdasarkan tabel 5 diketahui bahwa dari 49 responden dengan pendapatan dalam kategori rendah sebanyak 17 (9,7\%) orang memberikan imunisasi pada bayinya sementara 32 (18,2\%) orang lainnya tidak. Hasil uji statistik dengan menggunakan uji Pearson Chi-square diperoleh nilai $\mathrm{p}$ value $=0,018 \mathrm{p}<\alpha(0,05)$ artinya ada hubungan yang signifikan antara pendapatan dengan pemberian imunisasi rutin lengkap di Wilayah Kerja Puskesmas Inuman. Analisis nilai $\mathrm{OR}=3,43$ artinya responden yang memiliki pendapatan rendah negatif berpeluang 3,43 kali untuk tidak memberikan imunisasi rutin lengkap.

Tabel 6. Hubungan Dukungan Keluarga Terhadap Pemberian Imunisasi Rutin Lengkap Di Wilayah Kerja Puskesmas Inuman

\begin{tabular}{|c|c|c|c|c|c|c|c|c|}
\hline \multirow[t]{3}{*}{ Dukungan Keluarga } & \multicolumn{4}{|c|}{$\begin{array}{l}\text { Pemberian Imunisasi Rutin } \\
\text { Lengkap }\end{array}$} & \multirow{2}{*}{\multicolumn{2}{|c|}{ Jumlah }} & \multirow[t]{2}{*}{$\mathrm{P}_{\text {Value }}$} & \multirow{2}{*}{$\begin{array}{l}\text { OR } \\
(95 \% \\
\text { CI) }\end{array}$} \\
\hline & \multicolumn{2}{|c|}{ Diberikan } & \multicolumn{2}{|c|}{$\begin{array}{c}\text { Tidak } \\
\text { Diberikan }\end{array}$} & & & & \\
\hline & $\mathrm{F}$ & $\%$ & $\mathrm{f}$ & $\%$ & $\mathrm{f}$ & $\%$ & 0,000 & 0,31 \\
\hline Didukung & 99 & 56,2 & 45 & 25,6 & 144 & 81,8 & & $(0,245-$ \\
\hline Tidak didukung & 0 & 0 & 32 & 18,2 & 32 & 18,2 & & $0,398)$ \\
\hline Total & 99 & 56,2 & 77 & 43,8 & 176 & 100 & & \\
\hline
\end{tabular}

Berdasarkan tabel 6 diketahui bahwa dari 32 responden yang tidak didukung oleh keluarganya semuanya tidak memberikan imunisasi rutin lengkap pada bayinya. Hasil uji statistik dengan menggunakan uji Pearson Chi-square diperoleh nilai $\mathrm{p}$ value $=0,000 \mathrm{p}<\alpha(0,05)$ artinya ada hubungan yang signifikan antara dukungan keluarga dengan pemberian imunisasi rutin lengkap di Wilayah Kerja Puskesmas Inuman. Analisis nilai $\mathrm{OR}=0,31$ artinya responden yang tidak mendapatkan dukungan keluarga berpeluang 0,31 kali untuk tidak memberikan imunisasi rutin lengkap.

Tabel 7. Hubungan Keterjangkauan Ke Tempat Pelayanan Imunisasi Terhadap Pemberian Imunisasi Rutin Lengkap Di Wilayah Kerja Puskesmas Inuman

\begin{tabular}{|c|c|c|c|c|c|c|c|c|}
\hline \multirow{4}{*}{$\begin{array}{l}\text { Keterjangkauan } \mathrm{Ke} \\
\text { Tempat Pelayanan } \\
\text { Imunisasi }\end{array}$} & \multirow{2}{*}{\multicolumn{4}{|c|}{$\begin{array}{l}\text { Pemberian Imunisasi Rutin } \\
\text { Lengkap }\end{array}$}} & \multirow{3}{*}{\multicolumn{2}{|c|}{ Jumlah }} & \multirow[t]{3}{*}{$\mathrm{P}_{\text {Value }}$} & \multirow{3}{*}{$\begin{array}{l}\text { OR } \\
(95 \% \mathrm{C} \\
\text { I) }\end{array}$} \\
\hline & & & & & & & & \\
\hline & \multicolumn{2}{|c|}{ Diberikan } & & $\begin{array}{l}\text { idak } \\
\text { serikan }\end{array}$ & & & & \\
\hline & $\mathrm{f}$ & $\%$ & $\mathrm{f}$ & $\%$ & $\mathrm{f}$ & $\%$ & \multirow[t]{4}{*}{0,000} & \multirow{4}{*}{$\begin{array}{c}0,31 \\
(0,245- \\
0,398)\end{array}$} \\
\hline \multirow{3}{*}{$\begin{array}{l}\text { Terjangkau } \\
\text { Tidak Terjangkau } \\
\text { Total }\end{array}$} & 99 & 56,2 & 45 & 25,6 & 144 & 81,8 & & \\
\hline & 0 & 0 & 32 & 18,2 & 32 & 18,2 & & \\
\hline & 99 & 56,2 & 77 & 43,8 & 176 & 100 & & \\
\hline
\end{tabular}

Berdasarkan tabel 7 diketahui bahwa dari dari 32 responden yang tidak terjangkau ke tempat pelayanan imunisasi semuanya tidak memberikan imunisasi rutin lengkap pada bayinya. Hasil uji statistik dengan menggunakan uji Pearson Chi-square diperoleh nilai $\mathrm{p}$ value $=0,000 \mathrm{p}<\alpha(0,05)$ artinya ada hubungan yang signifikan antara keterjangkauan ke tempat pelayanan imunisasi dengan pemberian imunisasi rutin lengkap di Wilayah Kerja Puskesmas Inuman. Analisis nilai $\mathrm{OR}=0,31$ artinya responden yang memiliki tempat tinggal yang tidak terjangkau ke fasilitas pelayanan imunisasi berpeluang 0,31 kali untuk tidak memberikan imunisasi rutin lengkap. 


\section{PEMBAHASAN}

\section{Hubungan Tingkat Pengetahuan Ibu Terhadap Imunisasi Dengan Pemberian Imunisasi Rutin Lengkap Di Wilayah Kerja Puskesmas Inuman}

Hasil penelitian dapat diketahui bahwa dari 56 responden dengan kategori pengetahuan kurang hanya $4(2,3 \%)$ orang yang memberikan imunisasi rutin lengkap sedangkan $52(29,5 \%)$ responden tidak memberikan imunisasi rutin lengkap pada anaknya.

Hasil uji statistik dengan menggunakan uji Pearson Chi-square diperoleh nilai $\mathrm{p}$ value $=0,000 \mathrm{p}<\alpha$ $(0,05)$ artinya ada hubungan yang signifikan antara pengetahuan terhadap imunisasi dengan pemberian imunisasi rutin lengkap di Wilayah Kerja Puskesmas Inuman.

Hasil penelitian ini sesuai dengan penelitian Istriati (2011) yang menunjukkan ada hubungan antara tingkat pengetahuan ibu dengan kelengkapan imunisasi dasar pada bayi di Desa Kumpulrejo Kecamatan Argomulyo Kota Salatiga. Hal ini didasarkan pada hasil analisis dengan uji chi square diperoleh $p$ value $=0,004$ ( $p$ value $<0,05)$. Perhitungan risk estimate, diperoleh nilai odd ratio $(\mathrm{OR})=4,750$, sehingga dapat disimpulkan ibu dengan tingkat pengetahuan tinggi cenderung memberikan imunisasi dasar lengkap kepada anaknya, sebaliknya ibu dengan tingkat pengetahuan rendah memiliki risiko 4,750 kali tidak memberikan imunisasi dasar lengkap kepada anaknya.

Menurut asumsi peneliti adanya responden dengan pengetahuan baik namun tidak memberikan imunisasi kepada bayinya dan sebaliknya ada responden dengan pengetahuan kurang namun memberikan imunisasi pada bayinya dipengaruhi oleh berbagai faktor antara lain dukungan keluarga serta pendidikan responden. Menurut pengamatan peneliti di lapangan ibu-ibu bersemangat membawa anaknya pergi ke posyandu juga karena ingin berkumpul dengan ibu-ibu yang lain. Sedangkan pada ibu yang tidak membawa anaknya imunisasi juga dipengaruhi oleh faktor keyakinannya bahwa bayinya akan demam bila disuntik. Faktor lainnya adalah kepercayaan agama responden yang mengatakan bahwa imunisasi adalah zat yang haram untuk diberikan pada anaknya.

\section{Hubungan Pendidikan Terhadap Pemberian Imunisasi Rutin Lengkap Di Wilayah Kerja Puskesmas Inuman}

Hasil penelitian dapat diketahui bahwa dari 109 responden yang memiliki pendidikan rendah hanya $53(30,1 \%)$ responden yang memberikan imunisasi rutin lengkap pada bayinya sementara $56(31,8 \%)$ responden lainnya tidak memberikan imunisasi rutin lengkap pada bayinya.

Hasil uji statistik dengan menggunakan uji Pearson Chi-square diperoleh nilai $\mathrm{p}$ value $=0,018 \mathrm{p}<\alpha$ $(0,05)$ artinya ada hubungan yang signifikan antara pendidikan dengan pemberian imunisasi rutin lengkap di Wilayah Kerja Puskesmas Inuman.

Hasil penelitian ini sesuai dengan penelitian Istriati (2011) yang menunjukkan ada hubungan antara tingkat pengetahuan ibu dengan kelengkapan imunisasi dasar pada bayi di Desa Kumpulrejo Kecamatan Argomulyo Kota Salatiga yang mendapatkan hasil ada hubungan antara tingkat pendidikan ibu dengan kelengkapan imunisasi dasar pada bayi di Desa Kumpulrejo Kecamatan Argomulyo Kota Salatiga. Hal ini didasarkan pada hasil analisis dengan uji chi square diperoleh $p$ value $=0,008$ ( $p$ value $<$ 0,05). Perhitungan risk estimate, diperoleh nilai odd ratio $(\mathrm{OR})=4,297$, sehingga dapat disimpulkan ibu dengan tingkat pendidikan lanjut cenderung memberikan imunisasi dasar lengkap kepada anaknya, sedangkan ibu dengan tingkat pendidikan dasar memiliki risiko 4,279 kali tidak memberikan imunisasi dasar lengkap kepada anaknya.

Penelitian ini juga sesuai dengan penelitian yang dilakukan oleh Pratiwi (2012) yang menunjukkan hubungan yang bermakna antara pendidikan ibu dengan pemberian kelengkapan imunisasi balita. Ibu yang tidak bersekolah memiliki resiko 3,814 kali untuk pemberian imunisasi tidak lengkap dibanding ibu yang tamat perguruan tinggi.

Menurut asumsi peneliti adanya responden dengan pendidikan yang tinggi namun tidak memberikan imunisasi pada bayinya serta sebaliknya ada responden dengan pendidikan yang rendah namun memberikan imunisasi pada bayinya hal ini disebabkan oleh berbagai faktor antara lain dukungan keluarga serta sikap dari responden. Pendidikan responden yang rendah akan mempengaruhi ibu dalam pemberian imunisasi karena pendidikan yang rendah akan sulit dalam memahami tentang manfaat dan keuntungan pemberian imunisasi. Ibu dengan pendidikan yang tinggi akan mudah mencerna informasi yang diberikan oleh petugas kesehatan tentang pemberian imunisasi. 


\section{Hubungan Pekerjaan Terhadap Pemberian Imunisasi Rutin Lengkap Di Wilayah Kerja Puskesmas Inuman}

Hasil penelitian dapat diketahui bahwa dari $30(17,0 \%)$ responden yang tidak bekerja tidak ada seorang pun yang memberikan imunisasi rutin lengkap pada anaknya. Hasil uji statistik dengan menggunakan uji Pearson Chi-square diperoleh nilai $\mathrm{p}$ value $=0,000 \mathrm{p}<\alpha(0,05)$ artinya ada hubungan yang signifikan antara pekerjaan dengan pemberian imunisasi rutin lengkap di Wilayah Kerja Puskesmas Inuman.

Hasil penelitian ini sesuai dengan penelitian Istriati (2011) yang menunjukkan ada hubungan antara status pekerjaan ibu dengan kelengkapan imunisasi dasar pada bayi di Desa Kumpulrejo Kecamatan Argomulyo Kota Salatiga. Hal ini didasarkan pada hasil analisis dengan uji chi square diperoleh $p$ value $=0,000$ ( $p$ value $<0,05)$. Perhitungan risk estimate, diperoleh nilai odd ratio $(\mathrm{OR})=7,667$, sehingga dapat disimpulkan ibu yang tidak bekerja cenderung memberikan imunisasi dasar lengkap kepada anaknya, sebaliknya ibu yang bekerja memiliki risiko 7,667 kali tidak memberikan imunisasi dasar lengkap kepada anaknya.

\section{Hubungan Sikap Terhadap Pemberian Imunisasi Rutin Lengkap Di Wilayah Kerja Puskesmas Inuman}

Hasil penelitian dapat diketahui bahwa dari 32 responden dengan sikap dalam kategori negatif semuanya tidak memberikan imunisasi rutin lengkap pada bayinya. Menurut asumsi peneliti hal ini dipengaruhi oleh berbagai faktor antara lain dukungan keluarga serta tidak terjangkaunya tempat pelayanan kesehatan.

Hasil uji statistik dengan menggunakan uji Pearson Chi-square diperoleh nilai $\mathrm{p}$ value $=0,018 \mathrm{p}<\alpha$ $(0,05)$ artinya ada hubungan yang signifikan antara sikap dengan pemberian imunisasi rutin lengkap di Wilayah Kerja Puskesmas Inuman.

Hasil penelitian ini sesuai dengan penelitian Sari (2018) yang berjudul Faktor-Faktor Pada Ibu Yang Berhubungan Dengan Pemberian Imunisasi Dasar Bayi Di Wilayah Kerja Puskesmas Korpri Kecamatan Sukarame Kota Bandar Lampung yang mendapatkan hasil terdapat hubungan antara sikap ibu terhadap imunisasi dengan pemberian imunisasi dasar bayi di wilayah kerja Puskesmas Korpri Kecamatan Sukarame Kota Bandarlampung dengan $p$ value 0,009 dan OR 0,304. Ibu dengan sikap positif cenderung akan memberikan imunisasi dasar lengkap dibanding ibu dengan sikap negatif terhadap imunisasi.

Menurut asumsi peneliti hal ini dipengaruhi oleh berbagai faktor seperti rendahnya pengetahuan serta sikap responden, karena menurut peneliti seharusnya ibu yang tidak bekerja lebih banyak waktu untuk mengantarkan anaknya ke posyandu untuk imunisasi dibandingkan dengan ibu yang bekerja.

\section{Hubungan Pendapatan Terhadap Pemberian Imunisasi Rutin Lengkap Di Wilayah Kerja Puskesmas Inuman}

Hasil penelitian dapat diketahui bahwa dari 49 responden dengan pendapatan dalam kategori rendah sebanyak $17(9,7 \%)$ orang memberikan imunisasi pada bayinya sementara $32(18,2 \%)$ orang lainnya tidak. Hasil uji statistik dengan menggunakan uji Pearson Chi-square diperoleh nilai $\mathrm{p}$ value $=0,018$ $\mathrm{p}<\alpha(0,05)$ artinya ada hubungan yang signifikan antara pendapatan dengan pemberian imunisasi rutin lengkap di Wilayah Kerja Puskesmas Inuman.

Hasil penelitian ini sesuai dengan teori menurut Mulyanti (2013) yang mengatakan pemberian ekonomi seseorang berhubungan pada kemampuan seseorang membiayai pelayanan kesehatan. Seseorang mungkin tahu akan pentingnya kesehatan namun karena terkendala biaya orang tersebut memutuskan untuk tidak memperoleh pelayanan kesehatan yang dibutuhkannya. Pendapatan keluarga yang rendah akan menjadi pertimbangan ibu untuk tidak mengimunisasikan anaknya. Dampak lain adalah ibu lebih memilih bekerja untuk membantu pendapatan keluarga sehingga waktu untuk membawa anak imunisasi berkurang.

Hasil penelitian ini sesuai dengan penelitian Sari (2018) yang berjudul Faktor-Faktor Pada Ibu Yang Berhubungan Dengan Pemberian Imunisasi Dasar Bayi Di Wilayah Kerja Puskesmas Korpri Kecamatan Sukarame Kota Bandar Lampung yang mendapatkan hasil terdapat hubungan antara pendapatan keluarga dengan pemberian imunisasi dasar bayi di wilayah kerja Puskesmas Korpri Kecamatan Sukarame Kota Bandarlampung dengan $p$ value 0,007 dan OR 0,274. Ibu dengan tingkat pendapatan tinggi cenderung akan memberikan imunisasi dasar lengkap dibanding ibu dengan tingkat pendapatan rendah. 
Menurut asumsi peneliti adanya responden dengan pendapatan rendah namun memberikan imunisasi pada anaknya serta sebaliknya ada responden dengan pendapatan tinggi namun tidak mengimunisasi anaknya dipengaruhi oleh berbagai faktor antara lain tidak mendapatkan dukungan dari keluarga serta faktor pengetahuan yang kurang.

\section{Hubungan Dukungan Keluarga Terhadap Pemberian Imunisasi Rutin Lengkap Di Wilayah Kerja Puskesmas Inuman}

Hasil penelitian dapat diketahui bahwa dari 32 responden yang tidak didukung oleh keluarganya semuanya tidak memberikan imunisasi rutin lengkap pada bayinya. Hasil penelitian ini sesuai dengan teori yang dikemukakan oleh Notoatmodjo (2012) yang menyatakan bahwa untuk mewujudkan sikap menjadi suatu perbuatan yang nyata diperlukan faktor pendukung atau suatu kondisi yang memungkinkan, antara lain adalah fasilitas. Sikap ibu yang positif terhadap imunisasi harus mendapat konfirmasi dari suaminya dan ada fasilitas imunisasi yang mudah dicapai, agar ibu tersebut mengimunisasikan anaknya. Disamping faktor fasilitas, juga diperlukan dukungan dari pihak lain misalnya suami, orang tua, mertua, dan saudara.

Hasil uji statistik dengan menggunakan uji Pearson Chi-square diperoleh nilai $\mathrm{p}$ value $=0,000 \mathrm{p}<\alpha$ $(0,05)$ artinya ada hubungan yang signifikan antara dukungan keluarga dengan pemberian imunisasi rutin lengkap di Wilayah Kerja Puskesmas Inuman.

Hasil penelitian ini sesuai dengan penelitian Istriati (2011) yang menunjukkan ada hubungan antara dukungan anggota keluarga dengan kelengkapan imunisasi dasar pada bayi di Desa Kumpulrejo Kecamatan Argomulyo Kota Salatiga. Hal ini didasarkan pada hasil analisis dengan uji chi square diperoleh $p$ value $=0,003$ ( $p$ value $<0,05)$. Perhitungan risk estimate, diperoleh nilai odd ratio $(\mathrm{OR})=5,714$, sehingga dapat disimpulkan ibu yang didukung anggota keluarganya untuk mengimunisasikan anaknya cenderung memberikan imunisasi dasar lengkap kepada anaknya, sebaliknya ibu yang tidak didukung anggota keluarganya untuk mengimunisasikan anaknya memiliki risiko 5,714 kali tidak memberikan imunisasi dasar lengkap kepada anaknya.

Hasil penelitian ini sesuai dengan penelitian Sari (2018) yang berjudul Faktor-Faktor Pada Ibu Yang Berhubungan Dengan Pemberian Imunisasi Dasar Bayi Di Wilayah Kerja Puskesmas Korpri Kecamatan Sukarame Kota Bandar Lampung yang mendapatkan hasil terdapat hubungan antara dukungan keluarga ibu terhadap imunisasi dengan pemberian imunisasi dasar bayi di wilayah kerja Puskesmas Korpri Kecamatan Sukarame Kota Bandar Lampung dengan $p$ value 0,004 dan OR 0,194. Ibu yang mendapat dukungan dari keluarga cenderung akan memberikan imunisasi dasar lengkap dibanding ibu yang tidak didukung.

Menurut asumsi peneliti dukungan keluarga sangat berpengaruh pada pemberian imunisasi. Ibu yang tidak mendapatkan dukungan dari suaminya untuk mengimunisasi anaknya akan merasa khawatir apabila terjadi sesuatu pada anaknya maka dirinyalah yang akan disalahkan oleh suaminya. Sedangkan ibu yang mendapatkan dukungan suaminya akan merasa lebih nyaman serta lebih mudah dalam mengantarkan anaknya ke posyandu untuk di imunisasi.

\section{Hubungan Keterjangkauan Ke Tempat Pelayanan Imunisasi Terhadap Pemberian Imunisasi Rutin Lengkap Di Wilayah Kerja Puskesmas Inuman}

Hasil penelitian dapat diketahui bahwa dari 32 responden yang tidak terjangkau ke tempat pelayanan imunisasi semuanya tidak memberikan imunisasi rutin lengkap pada bayinya.Hasil penelitian ini sesuai dengan teori menurut Agustina (2012) yang mengatakan salah satu faktor yang memhubungani pencapaian derajat kesehatan, termasuk pemberian kelengkapan imunisasi dasar adalah adanya keterjangkauan tempat pelayanan kesehatan oleh masyarakat. Kemudahan untuk mencapai pelayanan kesehatan ini antara lain ditentukan oleh adanya transportasi yang tersedia sehingga dapat memperkecil jarak tempuh, hal ini akan menimbulkan motivasi ibu untuk datang ketempat pelayanan imunisasi.

Hasil uji statistik dengan menggunakan uji Pearson Chi-square diperoleh nilai $\mathrm{p}$ value $=0,000 \mathrm{p}<\alpha$ $(0,05)$ artinya ada hubungan yang signifikan antara keterjangkauan ke tempat pelayanan imunisasi dengan pemberian imunisasi rutin lengkap di Wilayah Kerja Puskesmas Inuman.

Hasil penelitian ini sesuai dengan penelitian Istriati (2011) yang menunjukkan ada hubungan antara keterjangkauan ke tempat pelayanan imunisasi dengan kelengkapan imunisasi dasar pada bayi di Desa Kumpulrejo Kecamatan Argomulyo Kota salatiga. Hal ini didasarkan pada hasil analisis dengan uji chi square diperoleh $p$ value $=0,003(p$ value $<0,05)$.

Menurut asumsi peneliti adanya responden yang memiliki tempat tinggal yang jauh dari tempat pelayanan imunisasi namun memberikan imunisasi pada anaknya serta sebaliknya adanya responden yang memiliki tempat tinggal dekat dengan tempat pelayanan imunisasi namun tidak membawa anaknya ke 
posyandu untuk diimunisasi di sebabkan oleh berbagai faktor yaitu pengetahuan ibu yang masih tergolong rendah serta tidak adanya dukungan di dalam keluarga untuk memberikan imunisasi.

\section{KESIMPULAN}

Terdapat pengaruh tingkat pengetahuan, pendidikan, pekerjaan, sikap, pendapatan, dukungan keluarga dan keterjangkauan ke tempat pelayanan posyandu terhadap imunisasi dengan pemberian imunisasi rutin lengkap di Wilayah Kerja Puskesmas Inuman dengan nilai $p$ value: $<\alpha 0,05$.

\section{UCAPAN TERIMAKASIH}

Ucapan terima kasih penulis sampaikan kepada kepala Puskesmas Inuman yang telah memberikan data dan informasi sehingga terlaksananya penelitian ini di lapangan.

\section{DAFTAR PUSTAKA}

Agustina. 2012. Pedoman Imunisasi Di Indonesia. Jakarta : Badan Penerbit Ikatan Dokter Anak Indonesia.

Depkes RI. 2009. Pedoman penyelenggaraan imunisasi. Jakarta.

Keputusan Menteri Kesehatan Republik Indonesia. 2014. Penyelenggaraan Imunisasi. Kementerian Kesehatan Republik Indonesia.

Pratiwi. 2012. Imunisasi dan Vaksinasi. Yogyakarta: Nuha Offset.

Sari. 2018. Hubungan tingkat pengetahuan ibu tentang pentingnya imunisasi dasar dengan kepatuhan melaksanakan imunisasi dasar. Skripsi. Prodi D IV Kebidanan FIK UNIPDO Jombang.

Isriyati. 2011. Faktor yang berhubungan dengan pemberian imunisasi dasar lengkap pada bayi tahun 2015. JKMA. 10(2): 123-35. 